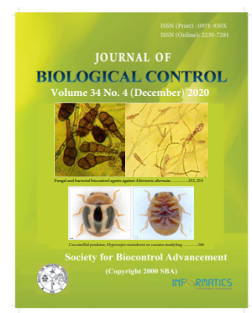

Research Article

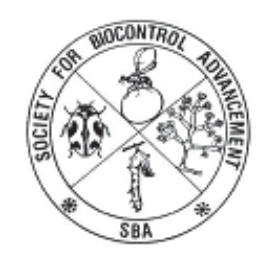

\title{
Evaluation of Bio-Intensive Pest Management (BIPM) module in rice var. Swarna at Raipur, Chhattisgarh
}

JAYALAXMI GANGULI, RASHMI GAURAHA, PRIYANKA NAGDEV and JHARNA CHATURVEDANI

Department of Entomology, College of Agriculture, Indira Gandhi Krishi Vishwavidyalaya, Raipur, Chhattisgarh - 492012, India

*Corresponding author Email: jayaganguli@yahoo.com

\begin{abstract}
Bio-Intensive Pest Management (BIPM) was tested in rice var. Swarna at the Instructional Research Farm and field behind the Biocontrol laboratory, IGKV, Raipur, Chhattisgarh for two years i.e 2018-19 and 2019-20 in comparison with farmer's practice and control as per the protocol given by ICAR-NBAIR, Bengaluru, under AICRP on Biocontrol. Results revealed that BIPM was significantly superior in comparison to the other two treatments as it recorded maximum yield during both the years. Also, significantly more number of natural enemies i.e. coccinellid beetles and spiders were recorded in BIPM treatment during both the years indicating its safety towards the native bioagents.
\end{abstract}

KEY WORDS: Bioagents, Bio-Intensive Pest Management, rice

(Article chronicle: Received: 11-11-2020; Revised: 27-12-2020; Accepted: 29-12-2020)

\section{INTRODUCTION}

Rice (Oryza sativa L.) is an essential source of food for more than three billion individuals and is one of the world's most significant staple crop. Rice is rich in significant amounts of B vitamins like thiamin, riboflavin, nicacin, essential trace element, zinc and other micronutrients apart from carbohydrates and proteins. India is the largest rice producing nation in the world after China.

Chhattisgarh popularly known as the rice-bowl of India, has been among country's five states, which ranked as major contributors of rice to the central pool occupying an area of 3760.50 lakh hactare with a production potential of 65.27 lakh tons (Indian Stat- 2018-19).

More than 100 species of insects are known to attack rice crop, of which the yellow stem borer, Scirpophaga incertulas Walker is one of the most destructive monophagous pests of this crop and is widely distributed in the Indian subcontinent (Atwal \& Dhaliwal, 2008). Though more than 28 insect species have been reported to attack rice in Chhattisgarh, the distribution and intensity of insect pest attack varies from zone to zone. In general, it has been estimated that about $25 \%$ of yield loss is due to insect pests of rice (Dhaliwal. et al. 2010). Leaf folder indicated maximum infestation at reproductive stage and decreases yield up to $6.2 \%$ (Chhavi, et al., 2016).

Bio-Intensive Pest Management (BIPM) is a systems approach that deals with management of pest based on understanding of pest ecology. It starts with steps to precisely analyse the nature and source of pest difficulties, and then depends on a range of preventive strategies and biological controls to maintain pest populations within acceptable limits. Pesticides at reduced risk are used if different strategies have not been sufficiently compelling, if all else fails, and with care to limit danger (Benbrook, 1996). BIPM targets on proactive measures to update the agricultural environment to deter a pest and to benefit its natural enemies (Dufour, 2001).

\section{MATERIALS AND METHODS}

\section{Experimental Layout}

The field trial was laid out in kharif season of 2018 and 2019 at the field behind Biocontrol laboratory, Department of Entomology and Instructional Research farm of College of Agriculture, IGKV, Raipur, Chhattisgarh, with the rice variety 'Swarna' in Randomized Block Design (RBD) with three treatments and eight replications (Plate 3). The 
treatments were BIPM, Farmer's Practice (FP) and control. The BIPM and FP comprised of a number of practices as mentioned below. Later the seedlings of appropriate age were transplanted to main field with a spacing of $20 \times 15 \mathrm{~cm}^{2}$ and all the recommended agronomic practices were followed to grow the rice crop. In BIPM plot, to enhance natural pest incidence on the crop, no application of pesticide was done throughout the crop period and chemical pesticides were applied in farmer's practice plot. Control plot was lacking both chemical and non-chemical practices.

\section{Experimental Details}

\section{Details}

\begin{tabular}{|l|l|l|}
\hline Location & $:$ & $\begin{array}{l}\text { Entomology research farm of IGKV, } \\
\text { Raipur (C.G.) }\end{array}$ \\
\hline Season & $:$ & Kharif 2018 and 2019 \\
\hline Crop & $:$ & Rice \\
\hline Variety & $:$ & Swarna \\
\hline Treatments & $:$ & 3 (BIPM, Farmer's Practice and Control) \\
\hline Replications & $:$ & 08 \\
\hline Design & $:$ & RBD \\
\hline Plot size & $:$ & $2023 \mathrm{~m}^{2} \times 3$ \\
\hline Spacing & $:$ & $20 \times 15 \mathrm{~cm}^{2}$ \\
\hline $\begin{array}{l}\text { Date of sow- } \\
\text { ing }\end{array}$ & $:$ & $07 / 07 / 2018 ; 09 / 07 / 2019$ \\
\hline $\begin{array}{l}\text { Date of trans- } \\
\text { planting }\end{array}$ & $:$ & $06 / 08 / 2018 ; 16 / 08 / 2019$ \\
\hline
\end{tabular}

\section{Treatment details}

\section{BIPM Module (T1)}

- Seed treatment with T. harzianum @15g/Kg,

- Seedling dip with Pseudomonas fluorescens 2\% solution (Plate 1),

- Spray of Azadirachtin1500ppm @3ml/litre at 45 \& 65 DAT against foliar and sucking pests,

- Erection of bird perches,

- Spray of P. fluorescens @ $1.5 \mathrm{Kg} / \mathrm{ha}$ against foliar diseases, and

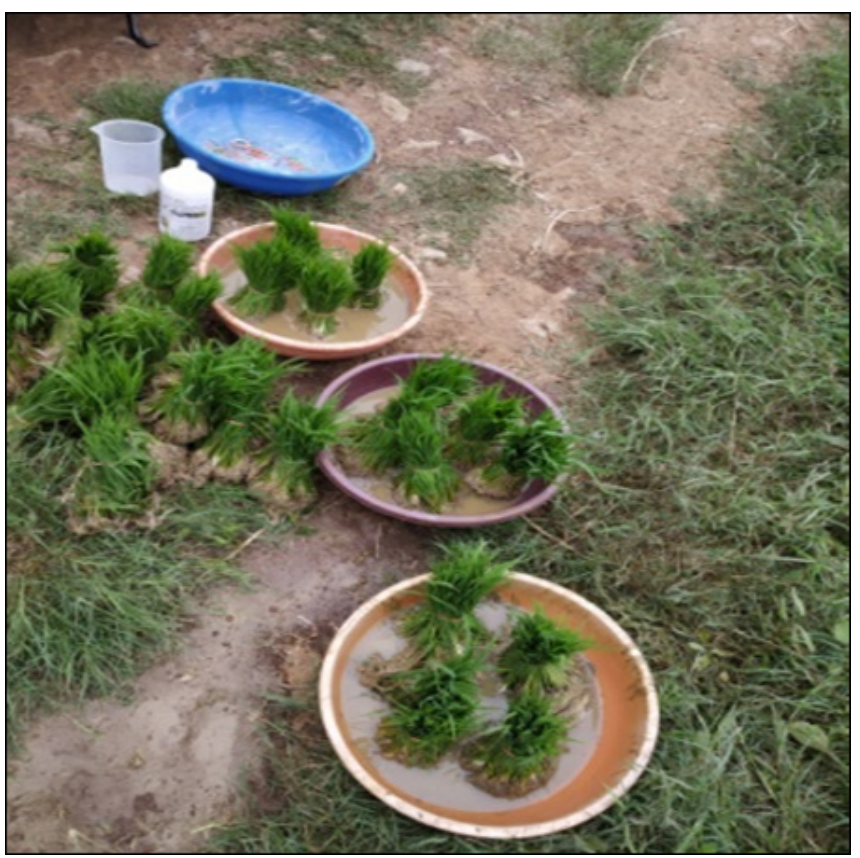

Plate 1. Treatment of rice seedlings

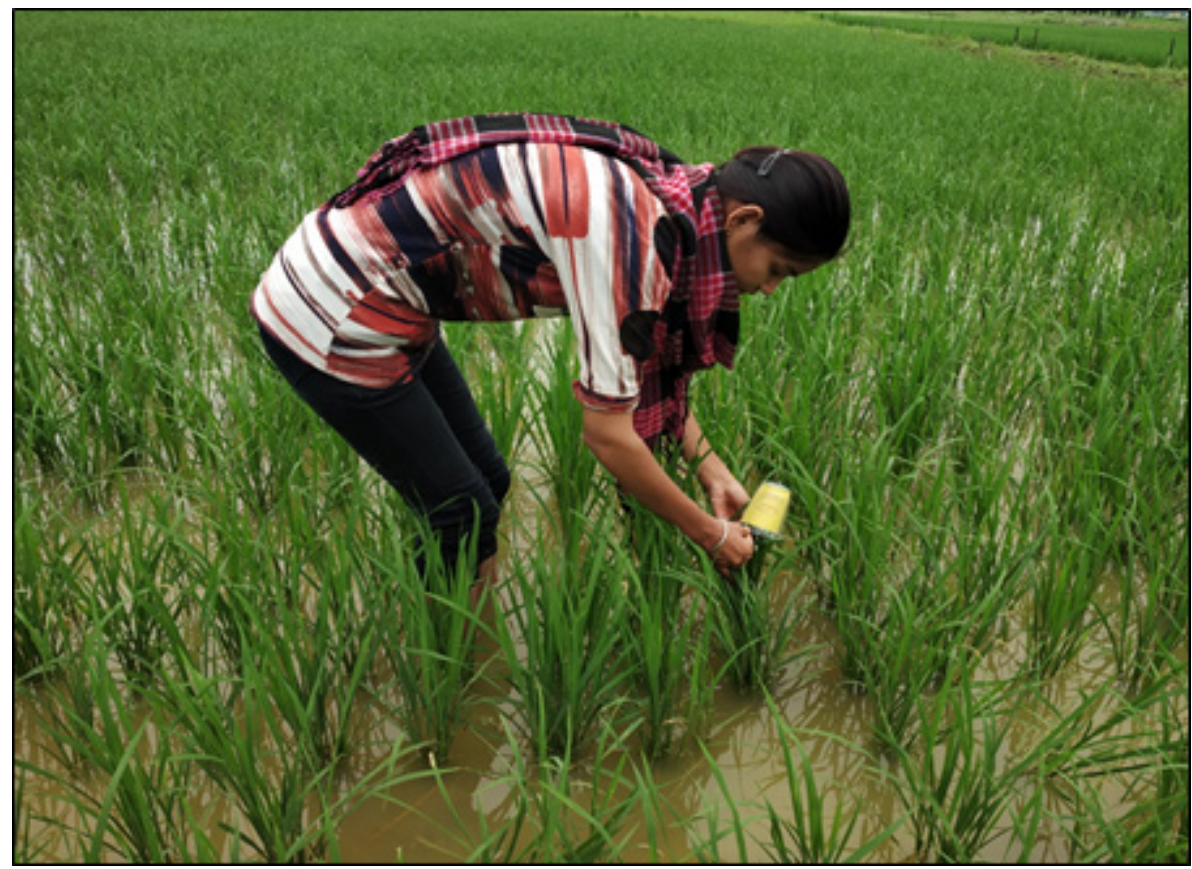

Plate 2. Application of Trichocard 
- Release of T. japonicum@1,00,000/ha (6 releases at 10 days interval starting from 25 DAT) (Plate 2)

\section{Farmer's Practice (T2)}

- Seed treatment with Carbendazim 50\%WP@2gm/Kg, and

- Spray of Chlorpyrifos 50\% + Cypermethrin 5\% EC.

\section{Control (T3): No treatment}

\section{RESULTS AND DISCUSSION}

(i) Per cent damage due to rice yellow stem borer, Scirpophaga incertulas (Walker) in the form of dead heart (DH) and white ear head (WEH)

Maximum percent of dead heart was recorded in control (13.73) and (12.20) in 2018 and 2019, respectively with a pooled mean per cent DH of 12.96, while minimum (8.024) and (8.50) was recorded in BIPM trial in 2018 and 2019, respectively (Table 1). Similarly maximum white ear head was recorded in control (22.40) and (20.51) in 2018 and 2019 , respectively with a pooled mean of 21.45 per cent, while minimum 15.68 and 15.58 was recorded in 2018 and 2019 in BIPM trial respectively, with a pooled average of 15.68 per cent. These findings are in agreement with Kaur. et al. (2008) where the organic practices and integrated practice with (seven releases of T. japonicum @ 1,00,000 each at weekly interval starting 30 DAT) proved to be effective in the management of stem borer in both the rice varieties viz., PR 116 and Basmati 386.

(ii) Percent leaf damage due to rice leaf folder, Cnaphalocrocis medinalis (Guenee)

Maximum damage due to rice leaf folder, $C$. medinalis in the form of percentage leaf folds was maximum in control (3.55) and 3.84 in 2018 and 2019 respectively, with a pooled mean of 3.69 percent while it was minimum in BIPM treated plot with 1.41 and 1.51 in 2018 and 2019 respectively, with a pooled average of 1.46 . This is in line with the findings of Lyla et al. (2010), who concluded after pooled analysis of three years data that, significantly lower incidence of leaf folder $(0.54 \%)$ was recorded in BIPM as compared to non BIPM practice $(0.96 \%)$ (Table 2$)$.

(iii) Percentage damage by case worm, Parapoynx stagnalis (Zeller) in rice var. Swarna in Kharif 2018 and 2019.

As per the data presented in Table 3 maximum damage due to case worm, P. stagnalis in the form of percentage of cases was maximum in control (0.255) and (0.33) in 2018 and 2019 respectively with a pooled average of 0.295 per cent while it was minimum in BIPM treated plot with (0.094) and 0.20 in 2018 and 2019 respectively with an average of 0.147 per cent cases.

\section{(iv) Damage due to rice hispa, Dicladispa armigera (Olivier)}

Non significant population of rice hispa, D. armigera was observed in 2018 but in 2019, it was significant with minimum population in BIPM (3.77) and maximum in control (4.64) while the pooled mean also depicted lowest population of hispa in BIPM treated plot (2.08) while maximum pooled mean population was recorded in control (2.54) (Table 4) (Plate 4 \& 5).

\section{(v) Population of BPH, Nilaparvata lugens (Stal)}

Data presented in Table 5 shows significant maximum damage due to BPH, $N$. lugens in control (5.43) with a pooled mean of 2.71 per cent and minimum population was in BIPM treated plot of recorded (2.00) with a pooled mean of 1.00. No population of BPH was observed in 2019.

\section{(vi) Population of GLH, Nephotettix sp.}

As per the Table 6 in 2018, significant maximum damage due to GLH, Nephotettix sp. was observed in control (1.33) nymphs and adult/plant with a pooled mean population of 0.66 and minimum (0.22) nymphs and adult/plant was recorded in BIPM treated plot with a pooled average of 0.11 nymphs and adult/plant. No incidence of GLH was observed in the year 2019 .
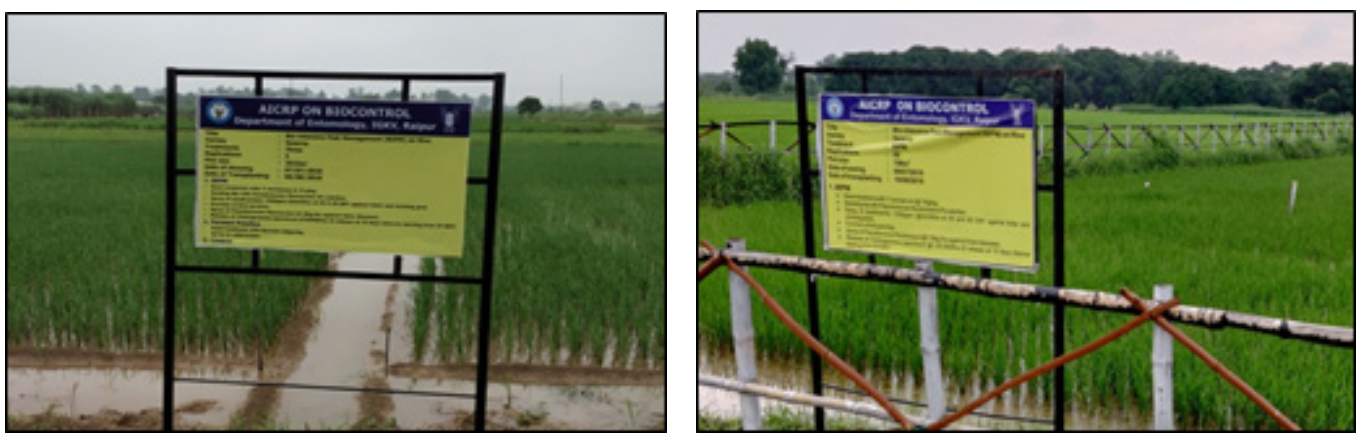

Plate 3. Experimental site of BIPM trials of rice var. Swarna in 2018 and 2019 
Evaluation of BIPM module in rice var. Swarna at Raipur, Chhattisgarh

Table 1. Per cent dead heart and white ear head recorded in rice var. Swarna in Kharif 2018 and 2019

\begin{tabular}{|c|c|c|c|c|c|c|c|c|}
\hline \multirow{2}{*}{$\begin{array}{c}\text { Treat- } \\
\text { ments }\end{array}$} & $\begin{array}{c}\text { Pre-treatment } \\
\text { mean }\end{array}$ & \multicolumn{2}{|c|}{ Mean Dead Heart (\%) } & \multicolumn{2}{c|}{ Pooled mean DH \% } & \multicolumn{2}{c|}{ Mean White ear head (\%) } & \begin{tabular}{c} 
Pooled \\
Mean \\
\cline { 2 - 9 } WEH \%
\end{tabular} \\
\hline T1 & $\mathbf{2 0 1 8}$ & $\mathbf{2 0 1 9}$ & $\mathbf{2 0 1 8}$ & $\mathbf{2 0 1 9}$ & & $\mathbf{2 0 1 8}$ & $\mathbf{2 0 1 9}$ \\
\hline T2 & $6.397(14.621)$ & $6.10(10.218)$ & $8.024(16.447)$ & $8.50(16.937)$ & 8.262 & $15.68(23.308)$ & $15.58(23.234)$ & 15.68 \\
\hline T3 & $6.648(15.00)$ & $7.40(12.573)$ & $11.89(20.166)$ & $11.24(19.574)$ & 11.56 & $19.22(25.988)$ & $18.01(25.099)$ & 18.61 \\
\hline CD & N/A & NS & 0.353 & 0.943 & & 0.503 & 0.522 & 21.45 \\
\hline SEm+ & 0.249 & 1.549 & 0.118 & 0.308 & & 0.168 & 0.171 & \\
\hline
\end{tabular}

Table 2. Per cent damage caused by leaf folder, $C$. medinalis in rice var. Swarna in Kharif 2018 and 2019

\begin{tabular}{|c|c|c|c|c|c|}
\hline \multirow{2}{*}{ Treatments } & \multicolumn{2}{|c|}{ Pre-treatment Mean } & \multicolumn{2}{|c|}{ Post treatment Mean leaf folder damage \% } & \multirow{2}{*}{$\begin{array}{l}\text { Pooled Mean leaf } \\
\text { folder damage } \%\end{array}$} \\
\hline & 2018 & 2019 & 2018 & 2019 & \\
\hline $\mathrm{T} 1$ & $0.586(3.333)$ & $0.75(4.638)$ & $1.41(6.790)$ & $1.51(7.040)$ & 1.46 \\
\hline $\mathrm{T} 2$ & $0.704(3.672)$ & $0.96(5.552)$ & $2.77(9.570)$ & $2.95(9.886)$ & 2.86 \\
\hline $\mathrm{T} 3$ & $0.7802(4.277)$ & $0.98(4.888)$ & $3.55(10.851)$ & $3.84(11.298)$ & 3.69 \\
\hline $\mathrm{CD}$ & NS & NS & 0.370 & 0.284 & \\
\hline SEm+ + & 0.525 & 0.726 & 0.123 & 0.093 & \\
\hline
\end{tabular}

Table 3. Per cent damage caused by case worm, P. stagnalis in rice var. Swarna in Kharif 2018 and 2019

\begin{tabular}{|l|c|c|c|c|c|}
\hline \multirow{2}{*}{ Treatment } & \multicolumn{2}{|c|}{ Pre-treatment Mean } & \multicolumn{2}{c|}{ Post treatment Mean percentage cases } & $\begin{array}{c}\text { Pooled mean of } \\
\text { percent cases }\end{array}$ \\
\cline { 2 - 6 } & $\mathbf{2 0 1 8}$ & $\mathbf{2 0 1 9}$ & $\mathbf{2 0 1 8}$ & $\mathbf{2 0 1 9}$ & 0.147 \\
\hline T1 & $0.32847(1.987)$ & $\mathbf{0 . 2 9}(\mathbf{2 . 1 0 7})$ & $0.094(1.232)$ & $\mathbf{0 . 2 0}(\mathbf{2 . 5 2 9})$ & 0.294 \\
\hline T2 & $0.18987(1.548)$ & $\mathbf{0 . 1 8}(\mathbf{1 . 4 6 7 )}$ & $0.299(3.078)$ & $\mathbf{0 . 2 9}(\mathbf{3 . 0 5 0})$ & 0.295 \\
\hline T3 & $0.25917(2.366)$ & $\mathbf{0 . 2 3}(\mathbf{1 . 9 2 0 )}$ & $0.255(2.184)$ & $\mathbf{0 . 3 3}(\mathbf{3 . 2 5 8})$ & $\mathbf{0 . 3 6 1}$ \\
\hline CD & NS & NS & 1.418 & $\mathbf{0 . 1 1 8}$ & \\
\hline SEm+ & 0.643 & $\mathbf{0 . 6 5 0}$ & 0.473 & \\
\hline
\end{tabular}

Table 4. Population of hispa, Dicladispa armigera recorded on rice var. Swarna during Kharif 2018 and 2019

\begin{tabular}{|c|c|c|c|c|c|}
\hline \multirow{2}{*}{ Treatments } & \multicolumn{2}{|c|}{ Pre-treatment mean } & \multicolumn{2}{|c|}{ Post treatment mean } & \multirow{2}{*}{ Pooled mean } \\
\hline & 2018 & 2019 & 2018 & 2019 & \\
\hline $\mathrm{T} 1$ & $0.88(1.165)$ & $8.47(16.886)$ & $0.40(1.182)$ & 3.77 (11.195) & 2.08 \\
\hline $\mathrm{T} 2$ & $0.68(1.291)$ & $5.91(14.045)$ & $0.39(1.177)$ & $3.92(11.407)$ & 2.15 \\
\hline $\mathrm{T} 3$ & $0.86(1.361)$ & 7.69 (16.079) & $0.45(1.202)$ & $4.64(12.426)$ & 2.54 \\
\hline $\mathrm{CD}$ & NS & 1.120 & NS & 0.361 & \\
\hline $\mathrm{SEm}+$ & 0.033 & 0.366 & 0.022 & 0.118 & \\
\hline
\end{tabular}

\section{Yield}

As far as yield was concerned, data presented in Table 7 indicates significant maximum grain yield $(28.41 \mathrm{~kg} / \mathrm{plot})$ and $31.56 \mathrm{Kg} /$ plot was obtained in BIPM in 2018 and 2019, respectively with maximum pooled mean of $(29.98 \mathrm{Kg} / \mathrm{plot})$ also recorded in BIPM treatment. Minimum grain yield of $22.98 \mathrm{~kg} /$ plot and $25.25 \mathrm{~kg} /$ plot was recorded in control during 2018 and 2019, respectively with a minimum pooled grain yield of $24.11 \mathrm{~kg} / \mathrm{plot}$.

As far as grain yield/acre was concerned, it was maximum in BIPM of 1280.44 and 1303.22 in 2018 and 2019, respectively, 


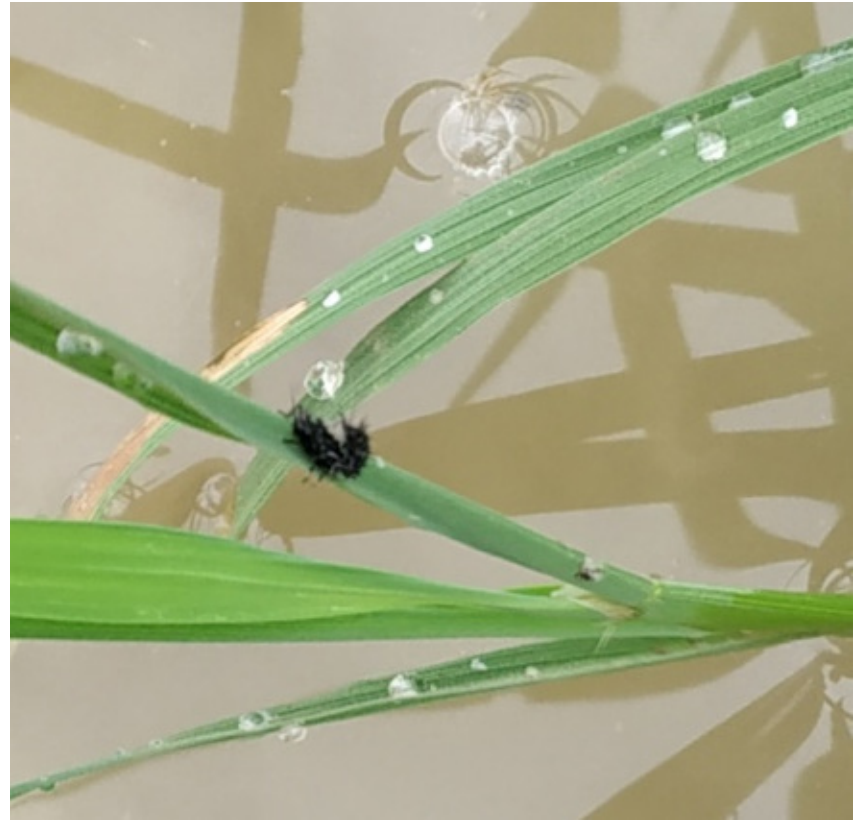

Plate 4. Adult hispa with leaf damage

Table 5. Population of BPH, $N$. Iugens recorded on rice var. Swarna during Kharif 2018 and 2019

\begin{tabular}{|c|c|c|c|c|c|}
\hline \multirow{2}{*}{ Treatments } & \multicolumn{2}{|c|}{ Pre-treatment } & \multicolumn{2}{c|}{ Post treatment } & \multirow{2}{*}{$\begin{array}{c}\text { Pooled } \\
\text { mean }\end{array}$} \\
\cline { 2 - 5 } & $\mathbf{2 0 1 8}$ & $\mathbf{2 0 1 9}$ & $\mathbf{2 0 1 8}$ & $\mathbf{2 0 1 9}$ & \\
\cline { 2 - 5 } & mean & mean & mean & mean & \\
\hline T1 & $\begin{array}{c}0.67 \\
(1.289)\end{array}$ & - & $\begin{array}{c}2.00 \\
(1.731)\end{array}$ & - & 1.00 \\
\hline T2 & $\begin{array}{c}0.71 \\
(1.307)\end{array}$ & - & $\begin{array}{c}1.69 \\
(1.637)\end{array}$ & - & 0.845 \\
\hline $\mathrm{T} 3$ & $\begin{array}{c}0.73 \\
(1.313)\end{array}$ & - & $\begin{array}{c}5.43 \\
(2.535)\end{array}$ & - & 2.71 \\
\hline $\mathrm{CD}$ & $\mathrm{NS}$ & - & 0.057 & - & \\
\hline $\mathrm{SEm}+$ & 0.015 & - & 0.019 & - & \\
\hline
\end{tabular}

where as it was minimum in control with 1041.69 and 1122.87 $\mathrm{kg} /$ acre in 2018 and 2019, respectively. In case of pooled mean of grain yield /acre also, it was maximum in BIPM $(1291.83 \mathrm{~kg})$ and minimum in control $(1082.28 \mathrm{~kg})$. The present finding is in match with Mohapatra (2008), which stated that the yield data of various treatments indicated that the BIPM plots recorded highest yield i.e., $4.6 \mathrm{t}$ ha-1 in comparison to FP (3.1 t ha-1) and CBP (4.4 t ha-1).

\section{Natural enemies recorded}

\section{(i) Population of coccinellids}

Significant maximum number of coccinellid (Micraspis sp.) were observed in BIPM (0.60) and (0.57) minimum (0.26) and (0.26) in farmers practice in the year 2018 and 2019 respectively, while the pooled mean

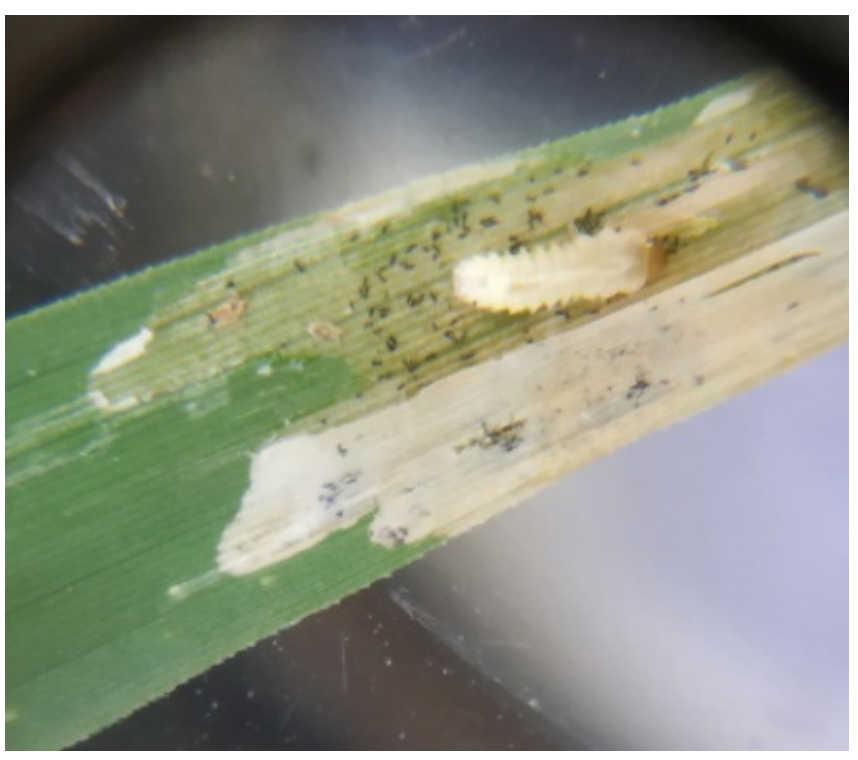

Plate 5. Grub of hispa with leaf scrapping

Table 6. Population of GLH, Nephotettix sp. recorded on rice var. Swarna during Kharif 2018 and 2019

\begin{tabular}{|l|c|c|c|c|c|}
\hline \multirow{2}{*}{ Treatments } & \multicolumn{2}{|c|}{$\begin{array}{c}\text { Pre-treatment } \\
\text { mean }\end{array}$} & \multicolumn{2}{c|}{$\begin{array}{c}\text { Post treatment } \\
\text { mean }\end{array}$} & \multirow{2}{*}{$\begin{array}{c}\text { Pooled } \\
\text { mean }\end{array}$} \\
\cline { 2 - 5 } & $\mathbf{2 0 1 8}$ & $\mathbf{2 0 1 9}$ & $\mathbf{2 0 1 8}$ & $\mathbf{2 0 1 9}$ & \\
\hline T1 & 0 & - & $\begin{array}{c}0.22 \\
(1.104)\end{array}$ & - & 0.11 \\
\hline T2 & 0 & - & $\begin{array}{c}1.33 \\
(1.525)\end{array}$ & - & 0.66 \\
\hline T3 & 0 & - & $\begin{array}{c}1.33 \\
(1.525)\end{array}$ & - & 0.66 \\
\hline CD & - & - & 0.027 & - & \\
\hline SEm & 0.015 & - & 0.009 & - & \\
\hline
\end{tabular}

population also depicted maximum number of coccinellids in BIPM (0.58) and minimum in Farmer's practice $(0.26)$ (Plate 7).

Lyla et al. (2010) also stated that higher population of coccinellid beetles/hill was found in BIPM (0.40\%) than $(0.06 \%)$ in non-BIPM which is in agreement with the present finding (Table 8).

\section{(ii) Population of spiders (Tetragnatha sp.)}

Significant maximum number of spiders was observed in BIPM (0.35) and (0.41) in 2018 and 2019 respectively, with maximum pooled mean of $(0.38)$ spiders, while minimum $(0.18)$ and $(0.23)$ spiders were recorded in farmers practice in 2018 and 2019, respectively with a pooled minimum population of (0.20). This matches with Lyla, et al. (2010), 
Evaluation of BIPM module in rice var. Swarna at Raipur, Chhattisgarh

Table 7. Mean grain yield of paddy (var. Swarna) in different treatments during Kharif 2018 and 2019

\begin{tabular}{|c|c|c|c|c|c|c|c|}
\hline \multirow{2}{*}{\multicolumn{2}{|c|}{$\begin{array}{c}\text { Treatments } \\
2018\end{array}$}} & \multicolumn{2}{|c|}{ Mean grain yield (Kg/plot) } & \multirow{3}{*}{$\begin{array}{c}\begin{array}{c}\text { Pooled mean grain } \\
\text { yield (Kg/plot) } \\
\mathbf{2 0 1 8}\end{array} \\
29.98 \\
\end{array}$} & \multicolumn{2}{|c|}{ Mean grain yield (Kg/acre) } & \multirow{2}{*}{$\begin{array}{c}\text { Pooled mean } \\
\text { grain yield } \\
\text { (Kg/acre) }\end{array}$} \\
\hline & & \multirow{2}{*}{$\begin{array}{l}2019 \\
28.41\end{array}$} & \multirow[b]{2}{*}{31.56} & & \multirow{2}{*}{$\begin{array}{c}2019 \\
1280.44\end{array}$} & \multirow[b]{2}{*}{1303.22} & \\
\hline $\mathrm{T} 1$ & BIPM & & & & & & 1291.83 \\
\hline $\mathrm{T} 2$ & Farmer's Practice & 25.25 & 28.88 & 27.06 & 1122.62 & 1284.63 & 1203.62 \\
\hline $\mathrm{T} 3$ & Control & 22.98 & 25.25 & 24.11 & 1041.69 & 1122.87 & 1082.28 \\
\hline \multicolumn{2}{|r|}{$\mathrm{CD}$} & 2.934 & 3.054 & & 140.96 & 136.652 & \\
\hline \multicolumn{2}{|r|}{$\mathrm{CV}$} & 12.131 & 9.874 & & 12.96 & 10.203 & \\
\hline
\end{tabular}
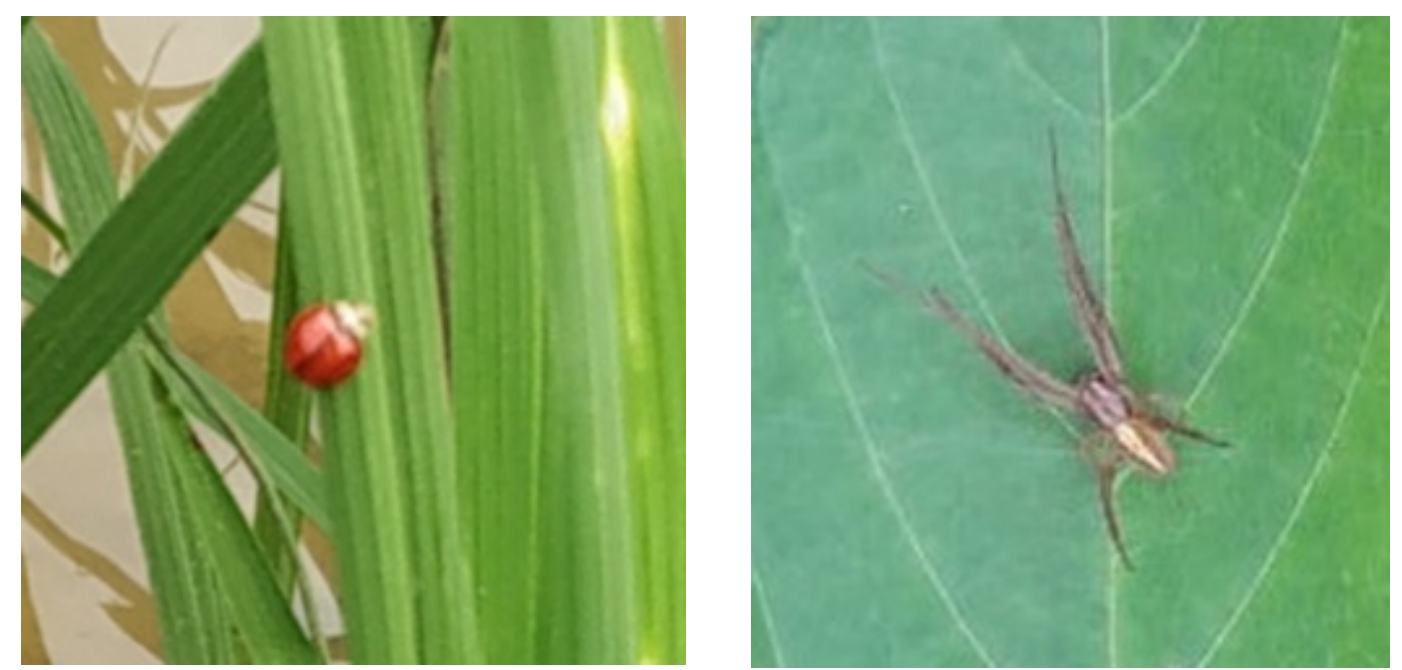

Plate 6. Natural enemies- Coccinellid, Micraspis sp. and Spider, Tetragnatha sp. recorded in BIPM field

Table 8. Population of coccinellid (Micraspis sp.) recorded in rice var. Swarna during Kharif 2018 and 2019

\begin{tabular}{|c|c|c|c|c|c|}
\hline \multirow{2}{*}{ Treatments } & \multicolumn{2}{|c|}{ Pre-treatment (Mean popln) } & \multicolumn{2}{|c|}{ Post treatment (Mean popln) } & $\begin{array}{c}\text { Pooled mean } \\
\text { popln }\end{array}$ \\
\cline { 2 - 5 } & $\mathbf{2 0 1 8}$ & $\mathbf{2 0 1 9}$ & $\mathbf{2 0 1 8}$ & $\mathbf{0 . 5 7}(\mathbf{1 . 2 5 1 )}$ & 0.58 \\
\hline $\mathrm{T} 1$ & $0.03(1.013)$ & $\mathbf{0 . 0 5}(\mathbf{1 . 0 2 4})$ & $0.60(1.265)$ & $\mathbf{0 . 2 6}(\mathbf{1 . 1 2 0})$ & 0.26 \\
\hline $\mathrm{T} 2$ & $0.02(1.010)$ & $\mathbf{0 . 0 4}(\mathbf{1 . 0 1 8})$ & $0.26(1.121)$ & $\mathbf{0 . 4 3}(\mathbf{1 . 1 9 4 )}$ & 0.45 \\
\hline $\mathrm{T} 3$ & $0.03(1.013)$ & $\mathbf{0 . 0 3}(\mathbf{1 . 0 1 2})$ & $0.47(1.211)$ & $\mathbf{0 . 0 1 7}$ & $\mathbf{0 . 0 0 6}$ \\
\hline $\mathrm{CD}$ & NS & NS & 0.042 & 0.014 & \\
\hline
\end{tabular}

Table 9. Population of spiders recorded in rice var. Swarna during Kharif of 2018 and 2019

\begin{tabular}{|c|c|c|c|c|c|}
\hline \multirow{2}{*}{ Treatments } & \multicolumn{2}{|c|}{ Pre-treatment mean } & \multicolumn{2}{|c|}{ Post-treatment mean } & \multirow{2}{*}{ Pooled mean } \\
\hline & 2018 & 2019 & 2018 & 2019 & \\
\hline $\mathrm{T} 1$ & $0.47(1.211)$ & $0.45(1.203)$ & $0.35(1.159)$ & $0.41(1.188)$ & 0.38 \\
\hline $\mathrm{T} 2$ & $0.47(1.211)$ & 0.25 (1.118) & $0.18(1.087)$ & $0.23(1.108)$ & 0.20 \\
\hline $\mathrm{T} 3$ & $0.32(1.149)$ & $0.28(1.128)$ & $0.21(1.100)$ & $0.25(1.120)$ & 0.23 \\
\hline $\mathrm{CD}$ & 0.028 & 0.046 & 0.038 & 0.012 & \\
\hline $\mathrm{SEm}_{+}$ & 0.009 & 0.015 & 0.013 & 0.004 & \\
\hline
\end{tabular}


Jayalaxmi Ganguli et al.

where significantly higher population of $(0.31 \%)$ spiders/hill in BIPM was recorded as compared to $(0.06 \%)$ in non-BIPM. Similarly, Sharma, et al. (2018) also reported that the mean population of spiders $(4.25 / \mathrm{plot})$ was significantly higher in BIPM practiced plots whereas, in farmer's practice plot it was (3.63/plot) which is in line with the present finding. This indicates that BIPM practices were safer for spiders as compared to farmer's practice (Table 9).

\section{CONCLUSION}

Thus, from the above studies it can be concluded that BIPM module were significantly superior than farmer's practice and control in both the years viz., 2018 and 2019. Significantly higher yield and more number of natural enemies viz., coccinellids and spiders were recorded in both the years in BIPM treated plots, which proves that BIPM is safer against naturally occurring bioagents.

\section{ACKNOWLEDGEMENT}

The authors are grateful to ICAR-NBAIR, Bangalore, for providing funds to IGKV, Raipur, Chhattisgarh, under AICRP on Biocontrol, without which the above studies would not have been possible.

\section{REFERENCES}

Atwal AS, Dhaliwal GS 2008. Agriculture pests of South India and their management. Kalyani Publishers, Ludhiana, Punjab, India.

Benbrook CM. 1996. Pest management at the crossroads. Consumers Union of United States Inc.
Chhavi, Srivastava A, Sharma PK. 2016. Populations buildup of rice leaf folder, Cnaphalocrocis medinalis (Guenee) under mid-hill conditions of Himachal Pradesh. J Insect Sci. 29:37-42.

Dhaliwal GS, Jindal V, Dhawan AK. 2010. Insect pest problems and crop losses: changing trends. Indian $J$ Ecol. 37(1):1-7.

Dufour, Rex. 2001. Biointenisve Integrated Pest Management. http://www.attra.ncat.org/attra-pub/PDF/ipm.pdf.

https://www.indiastat.com/agriculture-data/2/agricultural production/225/ rice/ 17194/stats.aspx. 2018-2019.

Kaur R, Brar KS, Kaur R. 2008. Management of leaf folder and stem borer on coarse and Basmati rice with organic and inorganic practices. J Biol Control. 22(1):137-141.

Lyla KR, Beevi SP, Philip BM, Jalali SK. 2010. Biological control of rice pests in 'Kole' lands of Kerala. J Biol Control. 24(3):268-270.

Mohapatra SD. 2008. Participatory appraisal for bio-intensive IPM research in Basmati rice: A case study. ORYZA-An Int. J. Rice. 45(2):175-177.

Sharma S, Shera PS, Sangha KS. 2018. Impact of biointensive integrated pest management practices on insect pests and grain yield in basmati rice. $J$ Biol Control. 32(2):137-141. https://doi.org/10.18311/ jbc/2018/16271. 